\title{
Islamic Bankers Green Behaviours and Its Impact on Green Banking Growth
}

\author{
Qaisar Ali* \\ Faculty of Islamic Economics and Finance, University Islam Sultan Sharif Ali \\ Brunei Darussalam

\section{Shazia Parveen} \\ Faculty of Management, Universiti Teknology Malaysia \\ Malaysia
}

*Corrosponding author's Email: aliqaisar21@gmail.com

Peer-review under responsibility of $4^{\text {th }}$ Asia International Conference 2018 editorial board (http://www.utm.my/asia/our-team/) (C) 2018 Published by Readers Insight Publisher, lat 306 Savoy Residencia, Block 3 F11/1,44000 Islamabad. Pakistan,

info@ readersinsight.net

This is an open access article under the CC BY-NC-ND license (http://creativecommons.org/licenses/by-nc-nd/4.0/). 


\section{Research High I ights}

This study focuses to categorise the types of green behaviours among Islamic bankers and the impact of these behaviours on the growth of green banking in Malaysia. The data was collected through a self-administrated survey questionnaire. McConnaughy's (2014) behavioural framework was adopted as a measurement scale. The findings prove that all five types of behaviours (conservation, work sustainability, avoiding harm, influencing others and taking initiative) of Islamic bankers have a significant positive impact on the growth of green banking. Particularly, taking initiative was the most influential behaviour for the growth of green banking. The major limitation of this study is the data collection from limited participants which is not an ideal scenario to generalise these findings. The findings are robust to develop green banking regulations, to shape a better green behaviour of Islamic bankers and to enhance green banking growth in Malaysia.

The major findings of this study are represented in below figure.

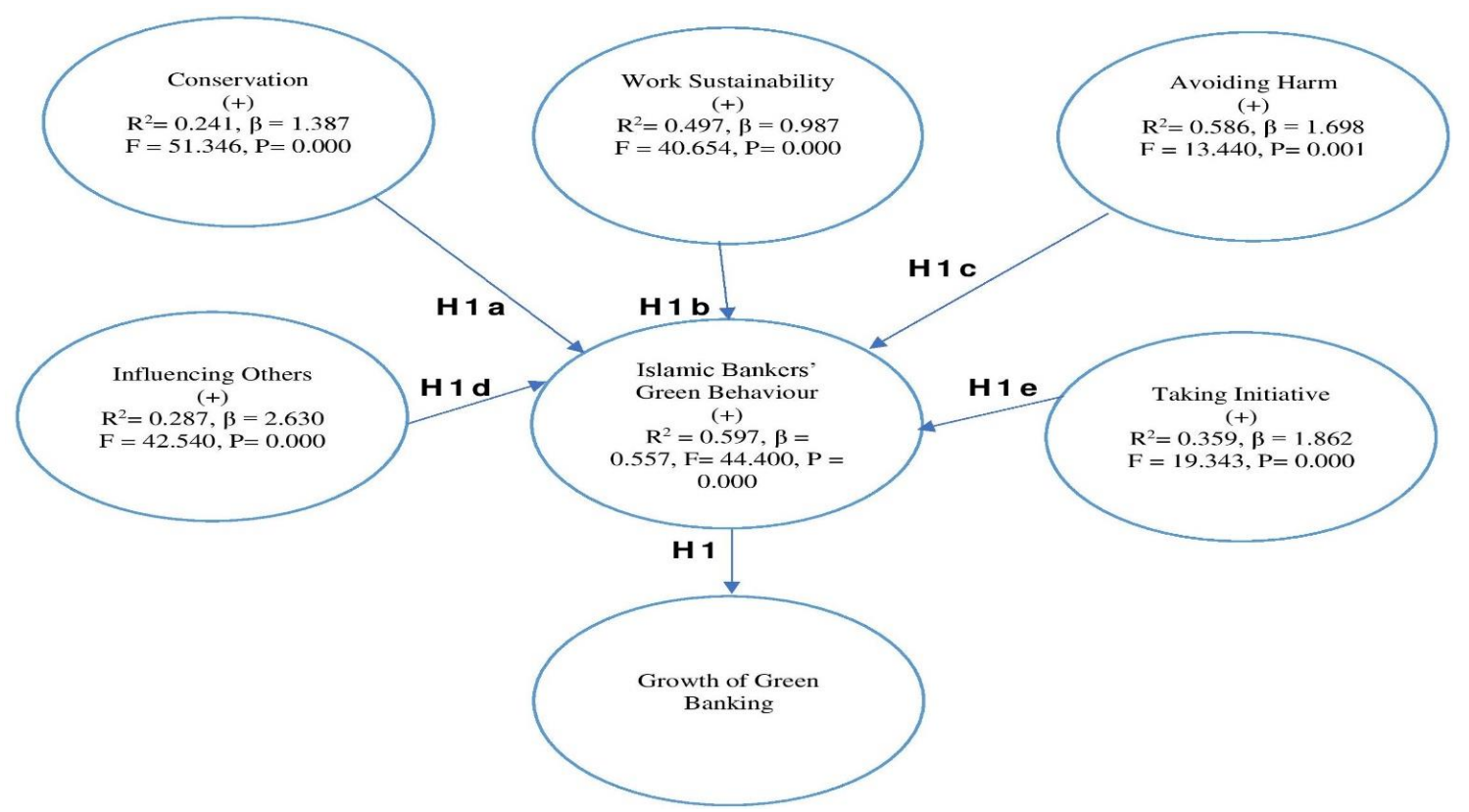

\section{Research Objectives}

The past studies have analysed the relationship between green banking and sustainability, Shariah compliance and financing on green projects (Oyegunle and Weber, 2015; Syedul and 


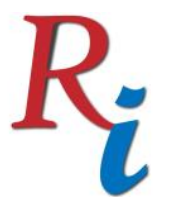

\section{Asia Proceedings of Social Sciences \\ (APSS) \\ www.readersinsight.net/APSS}

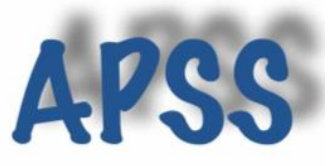

Islam, 2017; Uddin and Ahmmed, 2018; Khan and Mohomed, 2017; Julia et al, 2016; Uddin, 2016). The behavioural characteristics of Islamic bankers and its impact on the growth of green banking have largely remained unexplored in the literature. Therefore, this study aims to analyse the different green behaviours of Islamic bankers and the impact of each behaviour on the growth of green banking. Precisely, this study aims to elaborate Islamic bankers' green behaviours and how do these behaviours influence the growth of green banking.

The extended objectives of this research include the analyses of the role of senior management, employees' empowerment, training and rewards in shaping different green behaviours. It will help the management to enhance employees' participation through information sharing in stratgey development to achieve organizational goals and enhance its performance. The findings are expected to contribute to the development of green banking codes and regulations for sustainable growth of green banking. Based on the explored behaviours, Islamic bank managers may analyse the impact of corporate polices and practices on employees. The findings will assisst Islamic bankers to show better green behaviour for consistent growth of green banking.

\section{Methodology}

The conceptual framework of this study comprises of two variables namely Islamic bankers' green behaviour (IBsGB) which is an independent variable (predictor) and the the growth of green banking (GGB) which is a dependent variable (outcome). The data was collected from 55 Islamic bankers through a self-administrated survey questionnaire. The content of the questionnaire was designed using McConnaughy's (2014) measurement scale for green behavaiours. The questionnaire was divided into section ' $A$ ' and ' $B$ '. Section ' $A$ ' contained demographic variables of gender, age, religion, education level, rank and income per month. Section 'B' comprised of 26 item scale for the measurement of green behaviour. The respondents were provided with a 5-scale Likert option (strongly disgaree $=1$ to strongly agree $=5$ ) to answer the listed items.

The hypotheses were tested using stepwise multiple regression analysis. The following regression model was deployed to analyse the impact of different behaviours on the growth of green banking.

$\mathrm{GGB}=\alpha+\beta 1 \mathrm{IBsGB}+\beta 2 \mathrm{Cn}+\beta 3 \mathrm{WSn}+\beta 4 \mathrm{AHn}+\beta 5 \mathrm{TIn}+\beta 6 \mathrm{IOn}+\varepsilon \mathrm{n}$

Where, 


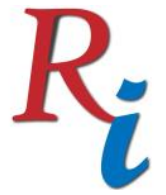

\section{Asia Proceedings of Social Sciences (APSS) \\ www.readersinsight.net/APSS}

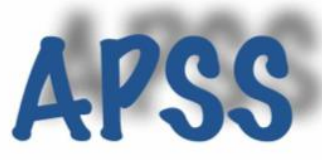

GBB represents growth of green banking, $\alpha$ denotes intercept term, $\beta$ denotes the regression coefficients, IBsGB, C, WS, AH, TI and IO represent Islamic bankers' green behaviour, conservation, work sustainability, avoiding harm, taking initiative and influencing others.

\section{Results}

The demographic analysis shows that about $44.66 \%$ (21) respondents were male and $53.33 \%$ were females. Most of (56.36\%) the respondents' age ranged between 30 to 39 years. $72.72 \%$ respondents were muslims and $40 \%$ held a bachelor degree. About $61.61 \%$ were employed as an executive and majority (54.54\%) of respondents' income was between 3, 001 to 5, 000 Ringgit Malaysia per month.

The consistency between the two variables was measured using Cronbach's alpha test. The findings show that the collected data was realiable as the alpha value was above the minimum criteria of 0.50 for all independent variables. The Pearson's correlation test was done to detect the multicollinearity issues in the adopted scale. The test results prove that the measurement model does not suffer from multicollinearity issues as the values of each factor was below the minimum criteria of 0.80 . The sampling adequacy of this research was measured through Kaiser-Meyer-Olkin (KMO) and Bartlett's test. The results prove that the collected data was realiable for further factor analysis as KMO values were above the threshold value of 0.50 (Leech et al, 2005). The hypotheses were tested using stepwise multiple regression analysis. The summaries of regression, ANOVA and cofficients prove that all hypotheses were supported.

\section{Findings}

The stepwise multiple regression analysis revealed that Islamic bankers' green behaviour has a significant positive impact on the growth of green banking. Similarly, results proved that all five types of green behaviours (conservation, work sustainability, avoiding harm, taking initiative and influencing others) have a significant positive impact on the growth of green banking in Malaysia. Especially, taking initiative behaviour was the most influencing type of green behaviour for the growth of green banking. 


\section{References}

Julia, T., Rahman, M. P. \& Kassim, S. (2016). Shariah compliance of green banking policy in Bangladesh. Humanomics, 32(4), 390-404, doi:10.1108/h-02-2016-0015.

Khan, T. \& Mohomed, A.B.R.N. (2017). Ethical Banking and Islamic Banking: A Comparison of Triodos Bank and Islami Bank Bangladesh Limited. Islamic Economic Studies, 25(Special issue), 111-154. DOI: 10.12816/0036190.

Leech, N.L., Barrett, K.C. and Morgan, G.A. (2005), "SPSS for intermediate statistics use and interpretation. Job Characteristics and Organizational Commitments of Taiwanese Expatriates Working in Mainland China", Li-Fen Tsai 180 Mahwah, Lawrence Erlbaum, USA.

McConnaughy, J.C. (2014). Development of An Employee Green Behaviour Descriptive Norms Scale. Theses published by California State University, San Bernardino.

Oyegunle, A. \& Weber, O. (2015). Development of Sustainability and Green Banking Regulations Existing Codes and Practices. CIGI Papers, 65.

Syedul, M.I., \& Islam, R.M. (2017). Is Islamic Banking More Sustainable Than Conventional Banking? An Empirical Study on Selected Banks of Bangladesh. Journal of Islamic Banking \& Finance, 34(1), 53-68.

Uddin, M.N. (2016). Shari'ah Based Banking and Green Financing: Evidence from Bangladesh. Journal of Business and Management, 18(1), 79-99, doi: 10.9790/487X-18137990.

Uddin, M.N. \& Ahmmed, M. (2018). Islamic Banking and Green Banking for Sustainable Development: Evidence from Bangladesh. Journal of Islamic Economics, 10 (1), 97-114, doi: htttp://dx.doi.org/10.15408/aiq.v10i1.4563. 